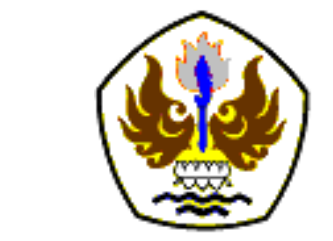

INFOMATEK

Volume 18 Nomor 1 Juni 2016

\title{
KAJIAN PROGRAM MAKANAN TAMBAHAN UNTUK ANAK SEKOLAH (PMT-AS) DI BANDUNG
}

\author{
Ira Endah Rohima* \\ Program Studi Teknologi Pangan \\ Fakultas Teknik - Universitas Pasundan
}

\begin{abstract}
Abstrak: Tujuan dari penelitian ini untuk mengkaji kinerja PMT-AS di Bandung, persepsi pihak sekolah mengenai pelaksanaan, manfaat, beban, kebutuhan, dan pelatihan dari PMT-AS, dan persepsi masyarakat mengenai pelaksanaan, manfaat, beban, kebutuhan dari PMT-AS. Desain penelitian ini adalah cross sectional study dan retrospective yang dilaksanakan di Kabupaten dan Kota Bandung. Pengambilan data primer dan sekunder dari responden pihak sekolah dan masyarakat yang berjumlah 54 orang. Pejabat Daerah di Bandung memberikan persepsi bahwa pelaksananan PMT-AS berjalan dengan baik (100\%), 75-100\% menilai bahwa PMT-AS memberikan manfaat, tidak menjadi beban (50-100\%), masih dibutuhkan (100\%).Pihak sekolah memberikan persepsi bahwa pelaksanaan PMT-AS berjalan dengan baik (100\%), 75-91,7\% pihak sekolah menilai bahwa PMT-AS memberikan manfaat (100\%), tidak menjadi beban(100\%), dan masih dibutuhkan (100\%). Masyarakat di Bandung memberikan persepsi bahwa pelaksanaan PMT-AS berjalan dengan baik (100\%), memberikan manfaat (90,9-100\%), dan tidak menjadi beban (100\%) dan masih dibutuhkan (100\%).
\end{abstract}

Kata kunci : PMT-AS, persepsi, responden

\section{PENDAHULUAN}

\subsection{Latar Belakang}

Murid Sekolah Dasar adalah masa pertumbuhan yang cepat dan kegiatan fisik yang aktif. Keturunan dan lingkungan merupakan determinan yang sangat penting dalam pertumbuhan dan perkembangan sekolah anak. Penyebab langsung seorang anak dapat tumbuh dan berkembang secara baik adalah cukupnya masukan gizi serta terbebasnya dari penyakit infeksi.

*iraendahrohima@unpas.ac.id
Pemerintah bertanggung jawab atas pendidikan, menyediakan sekolah cuma-cuma, dan mengharuskan wajib belajar karena banyak orang tua tidak mampu menyekolahkan anaknya. Keadaan tingkat kesehatan gizi anakanak di sebagian besar dunia menimbulkan keragu-raguan karena ketidakmampuan orang tua dalam menyediakan gizi yang cukup. Bila terjadi penyakit kurang gizi, maka pemerintah harus melakukan intervensi. Penyelesaian untuk membantu mengatasinya, pemerintah harus melakukan kegiatan (Berg [1]). 
Program makanan tambahan anak sekolah merupakan usaha yang dilakukan. Negaranegara berkembang dalam rangka memenuhi makanan bergizi. Di banyak Negara, program makanan tambahan berbeda jenisnya dan biasanya tergantung dari tujuan yang akan dicapai [1].

Program makanan tambahan untuk anak Indonesia dilaksanakan dengan latar belakang bahwa anak merupakan asset sumber daya manusia yang sangat penting guna membangun masa depan bangsa yang maju, mandiri, sejahtera, dan berkeadilan (Hidayat [2]).

Program Makanan Tambahan Anak Sekolah (PMT-AS) merupakan program pemerintah dengan memberikan makanan tambahan dan pemberian obat cacing dalam upaya peningkatan status gizi anak. Indikator keberhasilan PMT-AS meliputi peningkatan status gizi anak SD/MI, penurunan angka absensi, peningkatan nilai anak, penurunan angka infeksi kecacingan anak, serta peningkatan pengetahuan dalam aspek kesehatan. Tujuan PMT-AS berdimensi gizi, kesehatan, pendidikan, pertanian, ekonomi, dan pemberdayaan masyarakat. Sasaran PMT-AS berdimensi anak, orang tua murid, guru, dan masyarakat (Forum Koordinasi PMT-AS).

PMT-AS ini dilakukan tiga kegiatan yaitu pemberian makanan kudapan dengan syarat tertentu seperti menggunakan bahan lokal, tidak berbentuk makanan lengkap atau makanan pokok dan bersifat sebagai makanan suplemen bukan substitusi, selain itu makanan harus mengandung kurang lebih 300 kalori dan 5 gram protein untuk setiap kali pemberian. Kudapan diberikan tiga kali seminggu atau 108 kali dalam satu tahun ajaran. Kegiatan lainnya berupa pemberian obat cacing setiap dua kali per tahun serta penyuluhan pendidikan gizi dan kesehatan.

Penelitian sebelumnya menunjukkan hasil yang beragam mengenai pelaksanaan PMT-AS baik pengaruh positif seperti status gizi anak yang lebih baik tetapi di lain pihak belum memenuhi persyaratan gizi makanan yang diberikan sehingga perlu dilakukan kajian pada Program Makanan Tambahan Anak Sekolah (PMT-AS) yang telah dilaksanakan.

\subsection{Tujuan Penelitian}

Penelitian ini bertujuan untuk mengkaji :

1. Kinerja PMT-AS di Bandung

2. Persepsi pihak sekolah mengenai pelaksanaan, manfaat, beban, dan kebutuhan, dari PMT-AS

3. Persepsi pihak sekolah mengenai pelaksanaan, manfaat, beban, dan kebutuhan dari PMT-AS

\subsection{Manfaat Penelitian}

Hasil penelitian ini diharapkan dapat digunakan sebagai bahan masukan bagi pembuat dan pengambil kebijakan program dalam 
meningkatkan pelaksanaan program makanan tambahan bagi anak sekolah dasar sehingga dapat meningkatkan kualitas sumberdaya manusia di masa depan.

\subsection{Kerangka Pemikiran}

Program Makanan Tambahan Anak Sekolah (PMT-AS) merupakan salah satu komponen Program Perluasan Jaring Pengaman Sosial dan Penanggulangan Kemiskinan (PJPS-PK) sebagai upaya pemerintah untuk mengatasi masalah kurang gizi dan angka putus sekolah yang tinggi pada murid Sekolah Dasar. Selain itu diharapkan juga mampu memberdayakan orang tua murid dan masyarakat sehingga lebih memperhatikan pendidikan, gizi, dan kesehatan anak.

Pelaksanaan PMT-AS dipengaruhi oleh kinerja, persepsi, dan upaya oleh pihak terkait seperti pihak sekolah dan masyarakat. Kinerja PMT-AS mencakup input, proses, dan output. Input meliputi dana dari APBD, tenaga dari pihak terkait, sarana, prasarana, pelatihan dan penyuluhan. Proses mencakup perencanaan, pengorganisasian, pelaksanaan, evaluasi, dan pemantauan. Output meliputi peningkatan status gizi anak, penurunan angka absensi dan peningkatan nilai anak.

Dukungan berbagai pihak mulai dari pejabat daerah, pihak sekolah, dan masyarakat menentukan keberlangsungan pelaksanaan PMT-AS. Persepsi yang berbeda dapat mempengaruhi keberlanjutan suatu program. Persepsi tersebut dipengaruhi oleh pelaksanaan, manfaat, beban, dan kebutuhan. Persepsi pejabat daerah dipengaruhi oleh persepsi pihak sekolah dan masyarakat demikian sebaliknya pesepsi pihak sekolah dan masyarakat seipenaruhi oleh persepsi pejabat daerah.

\section{METODOLOGI}

\subsection{Desain dan Lokasi Penelitian}

Desain penelitian ini adalah cross-sectional study dan retrospectif dengan menggali informasi mengenai kinerja PMT-AS, persepsi dan upaya serta perbaikan dalam keberlanjutan PMT-AS. Penelitian dilaksanakan di Bandung meliputi Kabupaten dan Kota. Kabupaten Bandung merupakan daerah yang mempunyai resiko tinggi rawan pangan dan gizi dan Kota Bandung merupakan daerah yang mempunyai resiko rendah rawan pangan dan gizi.

\subsection{Teknik Penarikan Contoh}

Responden adalah pihak sekolah meliputi Kepala Sekolah, Dewan Sekolah dan guru SD dan $\mathrm{MI}$ dan masyarakat terutama orang tua murid, PKK, dan tokoh masyarakat yang ada di Kota dan Kabupaten Bandung. Pemilihan responden dilakukan secara purposif. Jumlah responden adalah 54 orang yang terdiri dari pejabat daerah 10 orang, pihak sekolah 24 orang dan masyarakat 20 orang. 
Tabel 1

Daftar Responden

\begin{tabular}{|l|c|c|c|}
\hline \multicolumn{1}{|c|}{ Responden } & \multicolumn{2}{|c|}{ Bandung } & \multirow{2}{*}{ Jumlah } \\
\cline { 2 - 3 } & Kota & Kab & \\
\hline 1. Pejabat Daerah & & & \\
- Dinas Pendidikan & 1 & 1 & 2 \\
- Dinas Kesehatan & 1 & 1 & 2 \\
- Puskesmas & 1 & 1 & 2 \\
- Kecamatan & 1 & 1 & 2 \\
- Kelurahan & 1 & 1 & 2 \\
\hline 2. Pihak Sekolah & & & \\
- Kepala Sekolah & 4 & 4 & 8 \\
- Guru & 4 & 4 & 8 \\
- Dewan Sekolah & 4 & 4 & 8 \\
\hline 3. Masyarakat & 4 & & \\
- Orang tua murid & 4 & 4 & 8 \\
- PKK & 1 & 3 & 8 \\
- Tokoh masyarakat & 21 & 23 & 44 \\
\hline
\end{tabular}

\subsection{Jenis dan Cara Pengumpulan Data}

Data yang dikumpulkan terdiri dari data primer dan data sekunder. Pengumpulan data primer dilakukan dengan melakukan wawancara berdasarkan kuesioner, sedangkan data sekunder diperoleh dari arsip yang diperoleh dari responden.

Data primer berupa wawancara dengan pejabat daerah, pihak sekolah, dan masyarakat untuk mengetahui persepsi, kebijaksanaan pemerintah, sumberdaya manusia, dan pengalokasian dana untuk PMT-AS. Data sekunder berupa arsip mengenai kinerja, data sekolah, data murid, pengalokasian dana, jalur pencairan dana, struktur APBD, dan kondisi wilayah.

\subsection{Pengolahan dan Analisis Data}

Data yang dikumpulkan merupakan data kualitatif dan diolah secara deskriptif. Data yang diolah mencakup sikap terhadap keberlanjutan
PMT-AS dari masyarakat dan pihak sekolah. Penelitian ini dapat dikatakan sebagai penelitian deskriptif kualitatif.Penilaian kinerja diperoleh dari laporan atau arsip di pejabat daerah, PKK, dan sekolah yang meliputi input, proses, dan output di Kota dan Kabupaten Bandung.

\section{HASIL DAN PEMBAHASAN}

\subsection{Keadaan Wilayah}

Bandung dan Bogor merupakan wilayah dengan penduduk yang cukup padat. Kabupaten Bandung merupakan daerah yang mempunyai resiko tinggi rawan pangan dan gizi dan Kota Bandung merupakan daerah yang mempunyai resiko rendah rawan pangan dan gizi.

Tabel 2

Keadaan Wilayah Bandung

\begin{tabular}{|l|l|l|c|c|}
\hline \multicolumn{1}{|c|}{ Wilayah } & \multicolumn{1}{|c|}{ Luas Wilayah } & $\begin{array}{c}\text { Jumlah } \\
\text { Penduduk }\end{array}$ & $\begin{array}{c}\text { Jml } \\
\text { Kec }\end{array}$ & $\begin{array}{c}\text { Jml } \\
\text { Desa }\end{array}$ \\
\hline Kota & $168,23 \mathrm{~km}^{2}$ & 1,461 juta & 30 & 151 \\
\hline Kab & $1.768 \mathrm{~km}^{2}$ & 3,418 juta & 31 & 280 \\
\hline
\end{tabular}

Sumber : Badan Pusat Statistik (2014)

Tabel 3

Kriteria Sasaran PMT-AS

\begin{tabular}{|l|l|l|}
\hline \multicolumn{1}{|c|}{ Kriteria } & \multicolumn{1}{|c|}{ Kota Bandung } & \multicolumn{1}{|c|}{ Kab Bandung } \\
\hline Desa & Desa tertinggal & Desa tertinggal \\
\hline $\begin{array}{l}\text { Sekolah } \\
\text { Dasar (SD) }\end{array}$ & $\begin{array}{l}\text { SD di daerah miskin } \\
\text { dari keluarga KS/KS1 }\end{array}$ & $\begin{array}{l}\text { SD dari keluarga } \\
\text { Pra Sejahtera }\end{array}$ \\
\hline $\begin{array}{l}\text { Madrasah } \\
\text { Ibtidaiyah } \\
\text { (MI) }\end{array}$ & $\begin{array}{l}\text { MI di daerah miskin } \\
\text { dari keluarga Pra } \\
\text { KS/KS1 }\end{array}$ & $\begin{array}{l}\text { MI di daerah miskin } \\
\text { dari keluarga Pra } \\
\text { Sejahtera }\end{array}$ \\
\hline $\begin{array}{l}\text { Pondok } \\
\text { Pesantren } \\
\text { (Ponpes) }\end{array}$ & $\begin{array}{l}\text { Ponpes di desa IDT } \\
\text { dengan usia santri 7- } \\
\text { 12 tahun }\end{array}$ & \\
\hline
\end{tabular}

Sumber : Badan Pemberdayaan Masyarakat 


\subsection{Keadaaan Sekolah}

Dalam penelitian ini, Sekolah Dasar (SD) dan Madrasah (MI) dipilih secara purposif. Di kabupaten Bandung dipilih 2 SD dan 2 MI sedangkan di Kota Bandung dipilih 2 SD dan 2 MI.

Tabel 4.

Lokasi Sekolah untuk contoh penelitian

\begin{tabular}{|c|c|c|c|}
\hline Wilayah & SD/M & Kec & Desa \\
\hline Kab & $\begin{array}{l}\text { SD. Cilampeni } \\
\text { SD. Margahayu } 7 \\
\text { MI. Miftahul Jannah } \\
\text { Ml. Al Haq }\end{array}$ & $\begin{array}{l}\text { Katapang } \\
\text { Margahayu } \\
\text { Katapang } \\
\text { Margahayu }\end{array}$ & $\begin{array}{l}\text { Pangauban } \\
\text { Margahayu } \\
\text { Katapang } \\
\text { Margahayu }\end{array}$ \\
\hline Kota & $\begin{array}{l}\text { SD. Cibuntu } 2 \\
\text { SD. Citarip } 3 \\
\text { MI. YPPI } \\
\text { MI. Salafiyah } 3\end{array}$ & $\begin{array}{l}\text { Bandung } \\
\text { Kulon } \\
\text { Bojongloa } \\
\text { Kaler } \\
\text { Bandung } \\
\text { Kulon } \\
\text { Bandung Kaler }\end{array}$ & $\begin{array}{l}\text { Warung } \\
\text { muncang } \\
\text { Kopo } \\
\text { Warung } \\
\text { muncang } \\
\text { Kopo }\end{array}$ \\
\hline
\end{tabular}

Pemilihan lokasi sekolah didasari oleh karakteristik yang berbeda dari sekolah-sekolah yang ada di kota dan kabupaten Bandung. Pemilihan lokasi dilihat dari keadaan bangunan sekolah, perbandingan guru dengan murid, dan kebun sekolah.

Tabel 5

Karakteristik sekolah yang menjadi contoh penelitian

\begin{tabular}{|l|l|l|l|l|l|}
\hline \multicolumn{1}{|c|}{ SD/MI } & $\begin{array}{c}\text { Jml } \\
\text { Murid }\end{array}$ & $\begin{array}{c}\text { Jml } \\
\text { Guru }\end{array}$ & $\begin{array}{l}\text { Jml } \\
\text { Kls }\end{array}$ & WC & Kebun \\
\hline SD. & 157 & 8 & 5 & 2 & Tdk ada \\
Cilampeni & 261 & 8 & 6 & 1 & Tdk ada \\
Margahayu 7 & 262 & 8 & 5 & 3 & Tdk ada \\
Cibuntu 2 & 298 & 6 & 3 & 3 & Tdk ada \\
Citarip 3 & & & & & \\
\hline MI. & 146 & 6 & 6 & 2 & Ada \\
Al Haq & 67 & 6 & 5 & 0 & Tdk ada \\
Miftahul & 181 & 4 & 6 & 2 & Tdk ada \\
Jannah & 225 & 13 & 8 & 1 & Tdk ada \\
YPPI & & & & & \\
Salafiyah 3 & & & &
\end{tabular}

3.3 Kinerja Program Makanan Tambahan Anak Sekolah (PMT-AS)

\subsubsection{Komponen Input}

1. Dana

Penyaluran dana PMT-AS dari Anggaran Pendapaan Belanja Daerah (APBD) dialokasikan ke rekening masing-masing kepala sekolah melalui Bank penyalur unit kecamatan seperti Bank Rakyat Indonesia di Kabupaten Bandung dan Bank Perkreditan Rakyat (BPR) dan Bank Jabar di Kota Bandung.

\section{Tenaga}

PMT-AS didukung bebagai pihak dari pejabat daerah, pihak sekolah, dan masyarakat. Pejabat daerah mempunyai kewenangan dalam membuat kebijakan mengenai pengalokasian dana, pelaksanaan dan mekanismenya. Pihak sekolah dan masyarakat merupakan tim pelaksana.

3. Sarana dan Prasarana Sarana PMT-AS adalah alat ukur tinggi dan timbangan badan, sedangkan prasarananya adalah alat masak, kebun sekolah, dan sarana air bersih.

4. Pelatihan dan Penyuluhan 
Pelatihan diberikan oleh tim pengelola tingkat kecamatan terutama Tenaga Pelaksana Gizi (TPG) kepada tim pelaksana. TPG Puskesmas berperan dalam melatih kelompok petugas masak dari PKK untuk membuat kudapan yan baik dan sesuai dengan standar, selain itu memantau dalam pengukuran berat dan tinggi badan.

\subsubsection{Komponen Proses}

1. Perencanaan

Perencanaan yang dilakukan adalah pengaggaran dana, pendatan lokasi sasaran, survey lokasi, sosialisasi, dan rapat koordinasi.

\section{Pengorganisasian}

Organisasi dimulai dari tingkat koordinasi kota/kabupaten sampai tingkat sekolah sebagai pelaksana.

3. Pelaksanaan

Pelaksanaan meliputi penyaluran dana, pemberian kudapan, dan pemberian obat cacing.

4. Evaluasi dan Pemantauan

Evaluasi dan pemantauan dilakukan oleh tim secara berjenjang. Pelaporan dlakukan setiap bulan.

\subsubsection{Komponen Output}

1. Status Gizi
Perbaikan status gizi diperoleh dari adanya peningkatan berat badan dan tinggi badan setelah pemberian PMT-AS.

Tabel 6

Persentase status gizi anak

\begin{tabular}{|l|l|c|c|}
\hline Wilayah & Status Gizi & $\begin{array}{c}\text { Sebelum } \\
\text { PMT-AS }\end{array}$ & $\begin{array}{c}\text { Sesudah } \\
\text { PMT-AS }\end{array}$ \\
\hline Kab & Kurang & $10,69 \%$ & $10,07 \%$ \\
& Baik & $85,51 \%$ & $85,87 \%$ \\
& Lebih & $4,04 \%$ & $4,06 \%$ \\
\hline Kota & Kurang & $12,05 \%$ & $7,64 \%$ \\
& Baik & $85,82 \%$ & $83,5 \%$ \\
& Lebih & $2,03 \%$ & $3,55 \%$ \\
\hline
\end{tabular}

Sumber : Dinas Kesehatan

\section{Prestasi Akademik}

Prestasi akademik yang dicerminkan oleh nilai mata pelajaran Matematika, IPS, dan IPA belum dapat menggambarkan dampak PMT-AS. Peningkatan dan penurunan prestasi tidak bisa dikaitkan dengan pemberian PMT-AS saja melainkan dipengaruhi oleh dukungan sekolah dan keluarga juga lingkungan murid untuk merangsang peningkatan prestasi tersebut.

3. Kebersihan diri dan lingkungan Kebersihan diri dan lingkungan meruoakan bagian dari penyelenggaraan PMT-AS yang dapat berdampak pada kehidupan seharihari. Kebersihan diri tercermin saat anak harus mencuci tangan sebelum makan juga saat membuang pembungkus makanan ke tempat sampah. 
4. Pengetahuan Gizi

PMT-AS diharapkan dapat meningkatkan pengetahuan gizi melibatkan guru, orang tua, dan murid. Namun penelitian sebelumnya di Kabupaten Bogor menunjukkan bahwa kegiatan PMT-AS belum memberikan dampak positif terhadap pengetahuan, sikap, dan perilaku gizi siswa.

\section{Persepsi mengenai pelaksanaan PMT-AS}

Responden seluruhnya menyatakan pelaksanaan PMT-AS berjalan dengan baik.

Tabel 7

Persepsi Pelaksanaan PMT-AS

\begin{tabular}{|l|c|c|c|c|}
\hline \multirow{2}{*}{ Responden } & \multicolumn{2}{|c|}{ Kabupaten } & \multicolumn{2}{c|}{ Kota } \\
\cline { 2 - 5 } & Baik & $\begin{array}{c}\text { Tidak } \\
\text { baik }\end{array}$ & Baik & $\begin{array}{c}\text { Tidak } \\
\text { baik }\end{array}$ \\
\hline Pejabat daerah & $100 \%$ & $0 \%$ & $100 \%$ & $0 \%$ \\
\hline Pihak sekolah & $100 \%$ & $0 \%$ & $100 \%$ & $0 \%$ \\
\hline Masyarakat & $100 \%$ & $0 \%$ & $90,9 \%$ & $9,1 \%$ \\
\hline
\end{tabular}

6. Persepsi mengenai manfaat PMT-AS

Manfaat PMT-AS meberikan persepsi yang berbeda, sebagian besar merasakan manfaat tapi sebagian kecil tidak merasakan manfaat dari pemberian PMT-AS.

Tabel 8

Persepsi mengenai manfaat PMT-AS

\begin{tabular}{|l|c|c|c|c|}
\hline \multirow{2}{*}{ Responden } & \multicolumn{2}{|c|}{ Kabupaten } & \multicolumn{2}{c|}{ Kota } \\
\cline { 2 - 5 } & $\begin{array}{c}\text { Ada } \\
\text { Manfaat }\end{array}$ & $\begin{array}{c}\text { Tidak } \\
\text { Manfaat }\end{array}$ & $\begin{array}{c}\text { Ada } \\
\text { Manfaat }\end{array}$ & $\begin{array}{c}\text { Tidak } \\
\text { manfaat }\end{array}$ \\
\hline $\begin{array}{l}\text { Pejabat } \\
\text { daerah }\end{array}$ & $100 \%$ & $0 \%$ & $75 \%$ & $25 \%$ \\
\hline Pihak sekolah & $91,7 \%$ & $8,3 \%$ & $75 \%$ & $25 \%$ \\
\hline Masyarakat & $100 \%$ & $0 \%$ & $90,9 \%$ & $9,1 \%$ \\
\hline
\end{tabular}

7. Persepsi mengenai beban PMT-AS

Pada umumnya PMT-AS tidak dianggap beban oleh sebagian besar responden. Persepsi dinilai beban bila ada kerugian yang dirasakan dari segi biaya, tenaga, moril, dan waktu.

\section{Tabel 9}

Persepsi mengenai beban PMT-AS

\begin{tabular}{|l|c|c|c|c|}
\hline \multirow{2}{*}{ Responden } & \multicolumn{2}{|c|}{ Kabupaten } & \multicolumn{2}{c|}{ Kota } \\
\cline { 2 - 5 } & Beban & $\begin{array}{c}\text { Tidak } \\
\text { beban }\end{array}$ & Beban & $\begin{array}{c}\text { Tidak } \\
\text { beban }\end{array}$ \\
\hline Pejabat daerah & $50 \%$ & $50 \%$ & $0 \%$ & $100 \%$ \\
\hline Pihak sekolah & $0 \%$ & $100 \%$ & $0 \%$ & $100 \%$ \\
\hline Masyarakat & $0 \%$ & $100 \%$ & $0 \%$ & $100 \%$ \\
\hline
\end{tabular}

8. Persepsi mengenai kebutuhan PMT-AS

PMT-AS diarasakan masih dibutuhkan oleh sebagian besar responden tetapi perlu adanya perbaikan pada mekanisme pelaksanannya.

Tabel 10

Persepsi mengenai kebutuhan PMT-AS

\begin{tabular}{|l|c|c|c|c|}
\hline Responden & \multicolumn{2}{|c|}{ Kabupaten } & \multicolumn{2}{c|}{ Kota } \\
\cline { 2 - 5 } & $\begin{array}{c}\text { Masih } \\
\text { dibutuh } \\
\text { kan }\end{array}$ & $\begin{array}{c}\text { Tidak } \\
\text { dibutuh } \\
\text { kan }\end{array}$ & $\begin{array}{c}\text { Masih } \\
\text { dibutuh } \\
\text { kan }\end{array}$ & $\begin{array}{c}\text { Tidak } \\
\text { dibutuh } \\
\text { kan }\end{array}$ \\
\hline Pejabat daerah & $100 \%$ & $0 \%$ & $100 \%$ & $0 \%$ \\
\hline Pihak sekolah & $100 \%$ & $0 \%$ & $100 \%$ & $0 \%$ \\
\hline Masyarakat & $100 \%$ & $0 \%$ & $100 \%$ & $0 \%$ \\
\hline
\end{tabular}

\subsection{Pembahasan}

Responden pada umumnya memberikan sikap yang positif terhadap pelaksanaan PMT-AS 
walaupun partisipasi untuk keberlanjutannya masih rendah. Partisipasi dalam kerangka arus dari atas (top down) seringkali melahirkan parisipasi yang artifisial dan cenderung bersifat mobilisasi. Keterlibatan masyarakat hanya dijadikan sebagai pelengkap, bukan yang utama. Partisipasi dipahami sebagai suatu kewajiban. Walaupun ada manfaatnya dari segi efisiensi waktu dan upaya pemaksaan program, pendekatan yang top down ini lebih efektif dan cepat.

Sebaliknya, pendekatan bottom up yang melibatkan masyarakat memiliki daya dukung yang kuat. Hal ini dapat dimengerti dan dipahami karena masyarakat telah menentukan sendiri apa yang terbaik bagi dirinya dan masyarakat sekitarnya. Pendekatan ini dapat dilakukan di masyarakat pada tahap memiliki keammpuan, semangat, dan antusiasme yang tingi serta memiliki kebersihan yang tinggi, maka kualitas dan kuantitas hasil pembangunan akan menunjukkan kemajuan yang signifikan.

PMT-AS saat ini mempunyai kerangka arus dari bawah (bottom up) sejak otonomi daerah diberlakukan. Secara konsep PMT-AS sangat relevan dengan keadaan saat ini karena keadaan ekonomi Indonesia yang masih belum stabil sehingga berdampak pada keluarga yang mayoritas sangat sulit untuk menyediakan makanan yang bergizi. Otonomi daerah memerlukan kerjasama dan harmonisasi hubungan antar daerah akan memperluas jangkauan pemanfaatan sumber daya dan berbagai hasil suatu daerah (Manan [3]).

Keberhasilan mengatasi masalah gizi merupakan tanggung jawab bersama. Berhasil atau gagalnya program juga dipengaruhi oleh sikap masyarakat terhadapnya. Apabila sikap ini menguntungkan maka masyarakat akan bertindak sesuai rencana program.

Perencanaan pembangunan daerah juga dikaitkan dengan keputusan politik dari pemerintah, maka ada hal tertentu yang harus dilaksanakan tanpa harus mengenyampingkan kepentingan kepentingan masyarakat, namun untuk jangka panjang kebijakan yang diambil harus sejalan dengan kesepakatan yang telah digariskan.

Pelaksanaan PMT-AS yang paling sering dikeluhkan responden adalah pencairan dana yang tidak tepat waktu dan tidak sesuai dengan jumlah murid. Hal ini terjadi karena kurangnya koordinasi tim pelaksana pada masing-masing tingkatan. Oleh karena itu diperlukan perencanaan yang lebih matang dalam mengantisipasi keterlambatan pencairan dana tersebut.

Pelaksanaan PMT-AS pada pengendalian dan evaluasi tidak optimal sehingga akan kesulitan dalam melihat keberhasilan program tersebut. 
Hal ini terjadi karena kurangnya kesadaran masyarakat pentingnya evaluasi program untuk melihat perkembangan yang terjadi setelah pemberian PMT-AS.

Manfaat PMT-AS memang dirasakan pengaruhnya tidak terlalu besar tapi tetap berdampak positif pada murid, sekolah, dan lingkungan. Ketahanan fisik murid yang lebih baik akan memberikan peluang menerima pelajaran lebih baik. Pengetahuan gizi tidak meningkat tetapi anak dibiasakan memilih makanan yang lebih baik saat jajan.

Memajukan perekonomian masyarakat adalah hal yang sulit dilakukan karena masyarakat sekitar mengelola kebun kurang beragam komoditinya sehingga upaya meningkatkan penghasilan masyarakat belum dapat tercapai. Kebutuhan makanan beragam tidak terpenuhi dari kebun masyarakat tetapi membeli dari pasar sekitar.

\section{KESIMPULAN DAN SARAN}

\subsection{Kesimpulan}

1. Kinerja PMT-AS mencakup input, proses, dan output.Input meliputi dana, tenaga, sarana, prasarana, pelatihan, dan penyuluhan. Proses meliputi perencanaan, pengorganisasian, pelaksanaan, evaluasi, dan monitoring. Ouput meliputi status gizi, angka absensi, prestasi akademik, dan pengetahuan gizi.
2. Pejabat Daerah di Bandung memberikan persepsi bahwa pelaksananan PMT-AS berjalan dengan baik (100\%), 75-100\% menilai bahwa PMT-AS memberikan manfaat, tidak menjadi beban (50-100\%), masih dibutuhkan (100\%).

3. Pihak sekolah memberikan persepsi bahwa pelaksanaan PMT-AS berjalan dengan baik (100\%), 75-91,7\% pihak sekolah menilai bahwa PMT-AS memberikan manfaat (100\%), tidak menjadi beban (100\%), dan masih dibutuhkan (100\%).

4. Masyarakat di Bandung memberikan persepsi bahwa pelaksanaan PMT-AS berjalan dengan baik (100\%), memberikan manfaat (90,9-100\%), dan tidak menjadi beban (100\%) dan masih dibutuhkan (100\%).

\subsection{Saran}

1. PMT-AS masih relevan dan dibutuhkan saat ini sehingga pembuat kebijakan setidaknya mempertimbangkan kembali penghapusan PMT-AS di Kabupaten atupun Kota Bandung.

2. Koordinasi, pemantauan, dan evaluasi lebih ditingkatkan untuk menunjukka keberhasilan program.

\section{DAFTAR PUSTAKA}

[1] Berg, A. 1986. Peranan Gizi dalam Pembangunan Nasional. Rajawali. Jakarta.

[2] Hidayat, S.1997. Membangun Sumber Daya Manusia yang Berkualitas, Suatu 
Infomatek Volume 18 Nomor 1 Juni 2016 : 17 - 26

Telaahan Gizi Masyarakat dan Sumber Daya Keluarga. Orasi IImiah. Fakultas Pertanian Bogor.
[3] Manan, B. 2001. Menyongsong Fajar Otonomi Daerah. Pusat Studi Hukum (PSH) Fakultas Hukum UII. Yogyakarta. 